\title{
Review of Robert Leeson's Hayek: a collaborative biography: part 1 Influences, from Mises to Bartley. New York: Palgrave Macmillan, 2013, 241 pp.
}

\author{
AGNIESZKA WINCEWICZ-PRICE \\ Newcastle University \\ Erasmus University Rotterdam
}

Given the vast literature both on Hayek and his work, one may wonder what contribution can be made by yet another study of the "greatest economic philosopher of his age". ${ }^{1}$ And yet this book endeavours something new, namely, "to connect Hayek's life to the sentiments he expressed". More specifically, the authors aim "to describe, interpret and integrate Hayek's life, beliefs and philosophy".

The book differs in many ways from a conventional biography, not least because it was co-authored by a group of fifteen scholars, among them historians, economists and political scientists. With such a large and diverse collection of authors, the book certainly manages to meet its aim of offering a variety of perspectives on Hayek and his life, work and influences, as well as his impact on intellectual and political history. However, it is debatable whether these multiple perspectives succeed in presenting an integrated picture of Hayek, which was the second major aim of this ambitious project. It is hard to resist the impression that this biography has no unifying theme, but remains merely a collection of vignettes-albeit sometimes very interesting ones.

Given that Hayek's intellectual contributions range from economics to political philosophy to epistemology, it may seem more than appropriate to attempt an intellectual biography as a collaborative effort, so that specialists can be brought to bear on his various intellectual accomplishments and their connections to his personal life. Rather than offering a complete and comprehensive analysis of the man and his work, this book offers an interesting supplement to the existing Hayek literature by detailing what other biographies and accounts of Hayek's ideas mention merely in footnotes or bibliographies. The authors took pains to consult a wealth of archival material and have used it to present Hayek as a person rather than merely as the label

\footnotetext{
${ }^{1}$ A photograph caption in the May 18, 1978 issue of the London Times.
} 
for a certain nexus of ideas. For this accomplishment they deserve high praise.

In at least one way, the book's diversity in form and content can be seen as an asset. The authors touch on a vast array of subjects-the selection of which has been handled deftly-and place them in their historical context, thus widening the scope of their analyses. Yet this method also makes the authors' individual contributions rather idiosyncratic. Among the more interesting discussions here are the back-story to, and the reception of, The road to serfdom; a brief critical review of Nicholas Wapshott's Keynes Hayek; the not unproblematic relations between Hayek and Mises; and Hayek's own reflections on his time in Freiburg.

The editor of the volume contributes the two longest chapters. Leeson's introduction gives a very good and engaging overview of Austrian economic thought and its clashes with the libertarian camp. It presents the themes covered by the other authors, in the context not only of Hayek's life but also of the origins and development of the Austrian School of Economics, itself analysed as part of a still bigger picture of classical economics. The editor then proceeds to distinguish four phases of Hayek's influence: his bringing the focus of the London School of Economics to Austrian economics; the unexpectedly broad reception of The road to serfdom (scorned by the left and mostly praised by the right); the impact of Hayek's Nobel Prize on the transformation of social sciences and public policy; and, finally, the 21 st century promotion of Hayek by Fox News.

Leeson later examines the complicated and controversial personality of the biographer that Hayek himself appointed, William Warren Bartley III. Bartley also initiated an unfinished project, The collected works of F. A. Hayek. Leeson's chapter is not a standard biographical essay but rather a lengthy exposition of some turbulent episodes in Bartley's intellectual and professional life, as well as his personal ailments and struggles. Bartley himself was an accomplished philosopher, whose $\mathrm{PhD}$ supervisor-none other than Karl Popper-is said to have described him as "the most gifted young philosopher he had ever met". The subject that interested Bartley most was rationality, which he studied both as a psychological faculty and as a foundation of scientific reasoning. But he was also well suited to writing biographies, and devoted a lot of his energies to that. He managed to complete two provocative and controversial biographies: one of Ludwig Wittgenstein 
and the other of Werner Erhard. His premature death did not allow him to finish biographies of Popper and Hayek.

Despite the initially adverse impression Hayek formed of Bartley, with time it turned out that these thinkers' interests and views, both professional and personal, overlapped. Both had broken off with the religious traditions of their families, and each in his own way was sceptical of religion's presence in the public sphere. But Hayek, unlike Bartley, had at least some appreciation for the role of Christian tradition, of its "symbolic truths" which "has created morals in modern civilization". Hayek was attracted to Bartley's theory of 'justificationism', which criticised the authoritarian structure of Western thought and epistemology wherein beliefs must be justified by appeal to an authority of some kind. Hayek's views on morality, however, seem to be marked by an important paradox. He was an advocate of strong moral conventionalism, resisting others' attempts to reform modern morality. Yet, as a rationalist he sought reasons for adhering to traditional morality. Rafe Champion's chapter investigates this apparent inconsistency in Hayek's liberal thought in more detail.

Three other chapters in this volume that deserve special mention examine the divisions between the Austrian and libertarian traditions. Douglas French's "Hayek and Mises" gives a fairly detailed account of the "curious" (as Hayek put it) relationship between the two great representatives of the Austrian school of economics. French outlines Hayek's appreciation and gratitude for Mises's help in his professional life, as well as the intellectual inspiration he gained from his first great mentor. Those less conversant with the various strands within the Austrian tradition will learn that Mises's influence on Hayek was not as great as might have been expected. Hayek thought the source of their intellectual differences lay in the fact that whereas he belonged to the liberal camp of English descent, Mises was more an heir of the European rationalist tradition of liberalism. The main areas of disagreement between the architect of praxeology and his most famous protégé appeared in the socialist-calculation debate and over Mises's "apriorist" methodology.

Victor Vanberg's noteworthy chapter is about Hayek's time in Freiburg and the conflicts within the classical liberal tradition. There is generally a lack of information about the ordoliberal Freiburg School in economic textbooks, and even courses in history of economic thought do not give it much attention. Its principal founder, Walter Eucken, was 
Hayek's close friend and, during Eucken's last four years of life, also a close collaborator. Eucken played an important role in the discussions which led Hayek to organize what was to become the founding meeting of the Mont Pelerin Society; he was also its only German participant. Ordoliberals were of the opinion that 'laissez faire' is not an adequate response to the needs of a free and humane society, and that the state must influence or directly establish the legal-institutional framework within which the economy works. Vanberg points out the important role of this theme in Hayek's work from the late 1930s until 1950, and the clash it caused between Hayek and some libertarian authors. He also touches upon the apparent tension between Hayek's views on the need for institutional framing and his later shift towards an evolutionary perspective. The chapter shows that Hayek felt very much at home in Freiburg, both intellectually and personally, by highlighting important details about Hayek's academic appointments there, along with some of his contemporaneous personal reflections.

The chapter by Nils Goldschmidt and Jan-Otmar Hesse further explores some aspects of the relationship between Hayek and Eucken, and consequently the differences between the German and the Austrian Schools of liberal thought-a subject largely neglected in the academic literature. The analysis is based on a letter from Eucken to Hayek in which he comments on The road to serfdom. While Vanberg's chapter presents the differences in Hayek's and Eucken's views as complementary, this chapter suggests that they were often contradictory. Examples include their different understandings of the relation between freedom and order; the conditions for and meaning of competition; and democracy. Some further research may be necessary in order to better judge the differences of interpretation between these two chapters. Still, it would seem that this discrepancy likely derives from a difference of emphasis rather than of substance. After all, both chapters address nuanced distinctions between two closely-related variants of liberalism, minor differences which pale in comparison with what unites Eucken and Hayek.

There is also a noteworthy chapter dealing primarily with the genesis and the reception of Hayek's most popular work, The road to serfdom. It provides an interesting analysis of a key set of texts which Hayek wrote between 1933 and the completion of the book in 1943. Melissa Lane argues against the commonly held idea that Hayek uncritically praised market liberalism by showing socialism to be 
inefficient. In fact-and this is not always remembered in many contemporary debates-Hayek was far from idealizing markets and, on the contrary, argued that the theoretical assumptions of idealized markets always needed to be confronted with the temporal dynamics experienced in actual markets. Lane also notes that, contrary to the common view, although the left found many of its ideas difficult to accept, The road to serfdom also contained much that was rather inconvenient to the right (e.g., the rejection of nationalism as a relevant principle in economic affairs).

It also deserves to be noted that Hayek refutes-or at least qualifies-some myths about the supposedly great animosity between Hayek and Keynes. This is a theme of the chapter by Selwyn Cornish, but is also touched upon elsewhere. As much as the two great economists differed significantly on many fundamental issues, there was also much that they agreed upon. It may be surprising to learn that Keynes was very complimentary of The road to serfdom. Among other things, he shared the view that, even with all its problems, market domination over individuals is nevertheless preferable to the exclusive state control of the economy. In political matters both men had a lot in common. And despite their grand differences of perspective on economic theory and policy, they very much held one another in high personal regard and intellectual respect.

Three yet unmentioned short chapters uncover some uncommon knowledge about Hayek. The chapter by Gabriel Söderberg, Avner Offer, and Samuel Bjork presents a technical but interesting analysis of patterns of academic citation of Hayek before and after receiving the Nobel Prize. Most winners of the prize see their citations peak shortly following its reception. But Hayek's award arrived at the tail end of the curve of citations to his academic work. The Prize, however, reinforced his authority and reputation, providing him with a citation boost that shifted him onto a much higher trajectory, as illustrated in one of the graphs included in the chapter. David Laidler's chapter attempts to solve the puzzle of the curious juxtaposition of the 1974 Nobel Prize recipients: Hayek and Myrdal. Another chapter, by Steven Dimmick and Robert Leeson, offers an interview with Stephen Kresge, Bartley's partner, who took over the Collected works of F. A. Hayek project. The interview adds first-hand clarification of some important matters mentioned in elsewhere in Hayek. 
At first it may seem surprising that a book about the work and influences of one great thinker gives so much attention to the biographical details of so many other famous intellectuals. It is apt then to recall what the great Goethe scholar, Nicholas Boyle, taught, namely, that a good biography focuses on secondary subjects and does not rely only on sources that originate from the subject. This collaborative biography certainly meets Boyle's standard in that it does not isolate Hayek's life and work from the rest of his world, but describes and interprets it through his connections and experiences with other scholars, events and institutions. Such an approach makes this biography all the more valuable and worthwhile.

Still, this collaborative biography is not to be recommended to a reader who has no prior knowledge of Hayek's work and ideas. Moreover, it is certainly not advisable as an introductory text for beginners; nor would it be a good choice for someone in search of a good summary of Hayek's life and work. For that, Bruce Caldwell's Hayek's challenge: an intellectual biography (2008) would be a much more suitable pick. It will, however, serve graduate students and researchers well. Anyone well acquainted with Hayek, but perhaps curious to learn more about his life and work, will not be displeased.

\section{REFERENCES}

Caldwell, Bruce. 2008. Hayek's challenge: an intellectual biography of F. A. Hayek. Chicago: University of Chicago Press.

Agnieszka Wincewicz-Price is a PhD candidate at Newcastle University and a research master student at Erasmus University. Her research interests lie in history of economic thought and theories of international political economy, with a special focus on the changing accounts of the human person in the history of economic ideas. Her doctoral dissertation investigates different understandings of moral human nature in micro- and macroeconomics.

Contact email: <agnieszka.wincewicz@gmail.com> 